\title{
Attractive Ecotourism, Professional Environmental Management, Poverty, and Social Capital Quality
}

\author{
Mochamad Ridwan \\ Economics and Business Faculty, University of Bengkulu, Indonesia \\ mochamadridwan61@gmail.com
}

\begin{abstract}
This research discusses the attractive ecotourism as one of the results of professional environmental management and is associated with poverty and social capital quality factors, both of which are considered as influencing factors. The three focuses of this study are the level of public awareness in participating in professional environmental management, attractive ecotourism, and two factors that influence it (poverty and social capital factors). The aim of this study is to explore the public awareness in the professional environmental management to produce attractive ecotourism, by conducting comparative studies from two provinces, namely Bengkulu and East Java. The analytical method used in this study is a qualitative analysis method (descriptive analysis method) which is supported by quantitative analysis methods, namely: Structural Equation Modeling Analysis. The results of the study indicate that, generally, ecotourism in the Bengkulu province is worse/lower/ less successful than in the East Java province in terms of attractiveness. The level of attractiveness of ecotourism is determined by the level of professionalism in ecotourism/environmental management (as a form of high and low performance). High and low levels of professionalism in ecotourism management, determined by poverty factor and quality of social capital factor. The quality of social capital (reflected in the attitude of participation/togetherness, cooperation/networking, mutual trust, and awareness of being responsible for maintaining the environment sustainably), indirectly affects the ecotourism performance (attractive or not) through motivation/willingness to change.
\end{abstract}

Keywords: Ecotourism; Environmental; Professional Management;
Poverty, Social Capital

\section{INTRODUCTION}

The high and low of attractive ecotourism performance (as a result of environmental management), can not be separated from the contribution of the influence (directly and indirectly) of various factors, including the influence of community poverty factors that exist in an area. Another factor whose influence is considered very important for environmental 
development, especially ecotourism-based development is a social capital factor. This is reasonable because success in a development process is always related to the success of human resource development, which is socially/group often referred to as social beings or seen from the values of asset/institutional capital contained therein, often referred to as social capital. Human resource experts say that the existence of social capital occupies a strategic place and has a very strong relationship/interaction with two other aspects/factors, namely the quality of natural resources/environment and man-made capital, all of which are key factors in realizing sustainable development [1]-[3].

The attitude/behavior of people on the banks of the river, who are used to throwing garbage (waste water) from the rest of the food into river water flow - one example of attitudes/behavior is still low social capital/low attitudes/behavior to be responsible. There were the impact of environmental pollution on decreasing river water quality due to ammonia parameters which have "exceeded the quality standard". The implication of this study is that the behavior of people in the poor category (the assumption that they are domiciled in the riverside area), which generally indicates a low level of social capital owned, turns out to correlate with weak environmental management capabilities in the surrounding areas. Therefore, good and correct environmental management is needed, taking into account the factors of social capital and poverty that exist in the community with various characteristics possessed [4].

Related to the importance of the relationship between aspects/factors of poverty, aspects/factors of social capital, ecotourism performance (as a form of ecotourism-based environmental management capabilities), comparison and benchmarking between regions (provinces) that have good/successful environmental management (ecotourism) regions (provinces) that have not been good/have not been successful are very important. In the context of studies, comparative analysis or benchmarking will be carried out between Bengkulu Province and East Java Province. For the record, the poverty rate that occurred in Bengkulu Province tended to decrease until it reached an average rate of 10.98 percent per year (until 2018); while the poverty rate in East Java Province, the numbers tend to decline to reach an average of 15.38 percent per year (up to 2018).

\section{METHOD}

Data used were primary data and secondary data, which were conducted in two different places/region (provinces), namely East Java Province and Bengkulu Province, with different times. The reason why this study took two different locations is two locations sampled had different characteristics seen from three aspects, namely (1) differences in ecotourism performance, (2) differences in poverty levels, and (3) differences in social capital.

The primary data were obtained through interview methods, focus group discussion methods, questionnaire methods, and observation methods. The number of samples involved for Structural Equation Modeling Analysis was 109 respondents, while for key informants involved in the interview process were 69 informants. All samples were taken through the Purposive Sampling Method. The secondary data were obtained through documentation method from BPS Indonesia, East Java Province, and Bengkulu Province [5]-[7]

This study uses qualitative method and quantitative method as supporters. The analytical method used in this study (for primary data) is a Descriptive Method which is supported by Quantitative Method: Structural Equation Modeling Analysis Method and it was used for 
answering the causality between determinants (influencing factors) with factors that are influenced. Both analysis methods have relationships that support each other.

\section{RESULT AND DISCUSSION}

The result of research conducted in two provinces, namely Bengkulu Province and East Java Province, can be shown in detail in Table 1.

Table 1. Percent of Poverty Level in East Java and Bengkulu Provinces in Indonesia 2015 -

\begin{tabular}{ccccccc}
\hline No. & Provinces & $\begin{array}{c}\text { Percent of } \\
\text { Poverty } \\
\text { Level } \\
(2015)\end{array}$ & $\begin{array}{c}\text { Percent of } \\
\text { Poverty } \\
\text { Level } \\
(2016)\end{array}$ & $\begin{array}{c}\text { Percent of } \\
\text { Poverty } \\
\text { Level } \\
(2017)\end{array}$ & $\begin{array}{c}\text { Percent of } \\
\text { Poverty } \\
\text { Level } \\
(2018)\end{array}$ & $\begin{array}{c}\text { Level of } \\
\text { Poverty until } \\
2018\end{array}$ \\
\hline 2. & Bengkulu & 17.16 & 17.03 & 15.59 & 15.38 & $\begin{array}{c}\text { First Level in } \\
\text { Sumatera } \\
\text { Moderate }\end{array}$ \\
East Java & 12.28 & 11.85 & 11.20 & 10.98 & \begin{tabular}{c} 
Level in Java \\
\hline
\end{tabular}
\end{tabular}

Source: Central Statistics Agency/BPS Indonesia (2018)

Table 1 shows that the poverty level in the Sumatra region, Bengkulu Province occupies the highest (first/high level) poverty level, which is 15.38 percent; while the level of poverty in the Java region, East Java Province occupies a moderate level of poverty (moderate level), which is equal to 10.98 percent.

Tendency of the poverty level differs significantly between the two regions (shown in Figure 1), which is also followed by differences in the development of its ecotourism performance. In the context of ecotourism performance (as a result of environmental management) in Bengkulu Province, the results of research obtained through observation methods and interview methods, indicate that the exotica of the charm of a variety of superior ecotourism, especially in the City of Bengkulu, has yet to show impressive performance. Environmentally, it can be said that its existence has not been able to present good environmental conditions (balance), meaning that there is still a lot of pollution in the form of garbage piles everywhere, a sense of belonging/nurturing of the surrounding environment that is still low, and others. An interesting example is the performance of the long beach ecotourism destination (natural environment based ecotourism), which is in an integrated place adjacent to the historical and cultural ecotourism destination-Fort Marlborough, which until now has not been managed well, so that it has not significantly impacted the increasing flow of tourists both locally, nationally and internationally due to the low pull factor.

Statistical data in BPS Bengkulu Province (2018) shows that tourist visits to Bengkulu are both local, regional, national and international; its performance from year to year has not been able to increase significantly and tends to be fluctuating. 


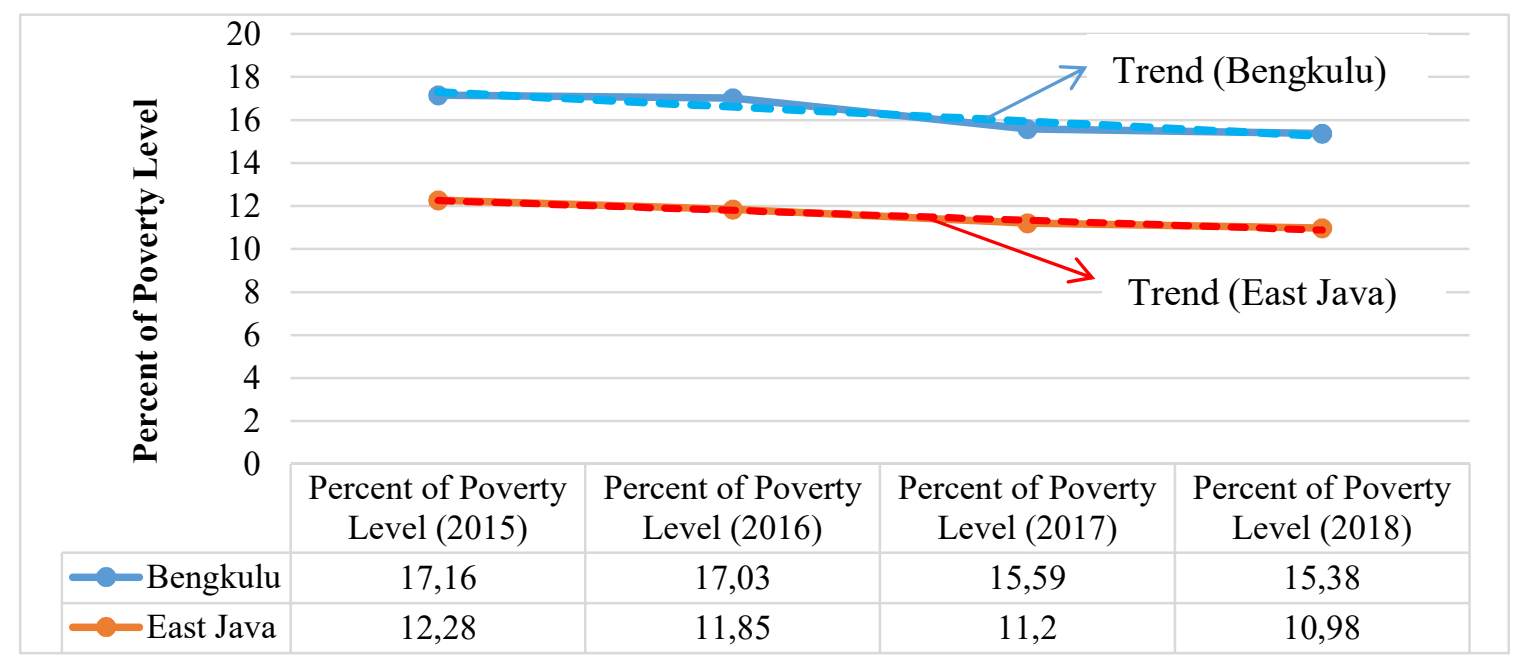

Figure 1. Trend of Development of Poverty Levels in the Bengkulu and East Java Provinces (2015-2018)

Research through methods of interviewing stakeholders related to social capital factors that influence the ability of the community in environmental management (ecotourism) indicated that in Bengkulu (with the City of Bengkulu as a sample of the research area), social capital factors are an important factor in streamlining and optimizing environmental management (ecotourism). One example, the results of interviews with several key Bengkulu figures (key informants) indicated that several indicators of social capital factors, such as the level of participation/maintaining the environment (environmental cleanliness) around the ecotourism area were still low, the mutual trust against the government as a still low, and environmental regulator (seen from its non-compliance with regulations in the form of prohibiting pollution), and others.

The results of research obtained through field observation methods, interviews, and secondary data studies, indicate that the environmental management in the form of ecotourism performance in East Java Province tend to increase and develop significantly from year to year. The report from BPS East Java Province (2018) shows that several regions in the East Java Province have made serious changes in entering the era of SDG'S (Sustainable Development Goals) with various efforts specifically in increasing pull factors through changes the mindset of comparative advantage becomes competitive advantage in the field of ecotourism-based development. For example, the Surabaya City was formerly referred to as a slum city, but now it has turned into a city of flowers that is beautiful city with a level of arrangement, cleanliness of the environment, and a high level of beauty; The Malang City which has now developed rapidly into a natural ecotourism city, with the beauty and cleanliness of an amazing environment, and there are still many other cities in East Java that have prepared their cities with serious environmental management in attracting tourists both local, regional national and foreign tourists.

Relating to the influence of social capital factor (the value of the working environment/institution that develops within a community group) that can shape good or bad or high and the low quality of a person's attitude/behavior such as high and low motivation to change better, level togetherness/participation, level of trust, etc., the results of research conducted in East Java show that social capital factors significantly influence a person's 
performance in a community group using analytical methods: Structural Equation Modeling (SEM). Graphically, the influence model is described through Figure 2 [8].

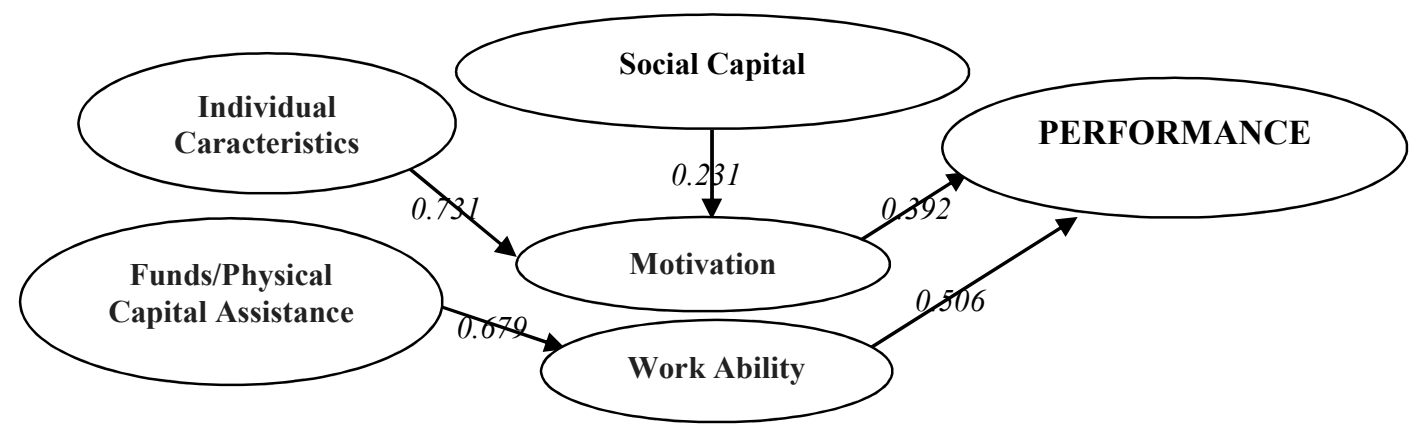

Figure 2. Model of the Effect of Social Capital on the Performance of the Environmental Management

In Figure 2, it appears that all the factors (Social Capital Factor through Motivation Factor) have a significant effect on the Performance Factor (with an error rate/alpha of 5 percent). Judging from the cross coefficient/parameter estimation of each factor, in general the value/number is relatively high. This indicates that all determinants/effects on the Performance factor are important and strategic factors, especially in consideration of decision making for a policy.

In conducting benchmarking between two provinces (Bengkulu Province and East Java Province), the results of the analysis of the three main aspects related to this research, namely attractive ecotourism performance, poverty level, and social capital are indispensable. Systematic description can be seen in Table 2.

Table 2. Quality Level of Ecotourism, Poverty Level, and Social Capital in East Java and Bengkulu Provinces

\begin{tabular}{lllll}
\hline No. & Provinces & $\begin{array}{l}\text { Quality Level of } \\
\text { Attractive Ecotourism } \\
\text { Performance }\end{array}$ & $\begin{array}{l}\text { Quality Level of Poverty } \\
\text { Rate }\end{array}$ & $\begin{array}{l}\text { Quality Level of } \\
\text { Social Capital }\end{array}$ \\
\hline 1. & Bengkulu & Low Level & $\begin{array}{l}\text { Highest Level in Sumatera } \\
\text { Middle Level in Java }\end{array}$ & $\begin{array}{l}\text { Low Level } \\
\text { High Level }\end{array}$ \\
\hline
\end{tabular}

If it is associated with efforts to optimize ecotourism performance in the form of increasing ecotourism attractiveness, the structural model found in Figure 2 explains that social capital factor (through Motivation factor) and work ability factor (associated with a reduction in poverty reduction in poverty) are two important and strategic factors in influencing Performance factor (Performance factor in the form of ecotourism attraction). Likewise, other factors such as individual characteristics and funding for financing are related to efforts to improve work capacity. In the model (see Figure 2), the motivation/ strong will to change is one of the important indicators that are formed by indicators (variables) of social capital, namely: participatory/togetherness/attitude, cooperation/networking, mutual trust, motivation/willingness to change in a better direction, and a level of awareness of responsibility. 
Based on benchmarking between Bengkulu Province and East Java Province (as stated in Table 2), the results of the research indicates there is a positive correlation between the quality of ecotourism performance, poverty levels, and the quality of social capital. The positive correlation has implications on inspiration about the efforts of a region to improve its performance, for example ecotourism-based performance, such as the problems that occur in Bengkulu Province, whose ecotourism performance is still low due to relatively high poverty rates, and quality of social capital is still low. In this context it can be further explained that if ecotourism performance is would be improved, then the poverty level must be suppressed and the quality of social capital in the community must be improved too.

\section{CONCLUSION}

Attractive ecotourism performance as a result of environmental management capabilities, in general, Bengkulu Province is worse/less successful when compared to East Java Province. Two important determinants that can determine/influence the variability (high and low) of ecotourism performance as a result of environmental management in the two provinces are (1) direct influence of high and low of poverty levels and (2) indirect effects of high and low of social capital quality (reflected in the attitude of participation/togetherness, cooperation/networking, mutual trust, and awareness of being responsible for the maintenance of the environment in a sustainable manner) through motivation/willingness to change factor. The result of structurally analysis (causality relationship), it can be concluded that high ecotourism performance can be obtained through hard and serious efforts, namely by repressing the level of poverty and empowerment, literacy, and education, so that the quality of the factor of social capital inherent in the community will be of better quality. Factor of social capital is important and key factors, because the four indicators that are owned are formative indicators, which means that the four indicators together determine the high and low of social capital quality.

\section{ACKNOWLEDGMENT}

The author expressed his gratitude to the Postgraduate Program in Economics, FEB UNIB for funding this research.

\section{REFERENCES}

[1] P. Dasgupta and I. S, Economic Progress and the Idea of Social Capital. Washngton DC: Word Bank, 1999

[2] F. Fukuyama, Social Capital and The Global Economy, vol. 74, no. 5. 1995.

[3] D. W. Pearce and G. D. Atkinson, "Capital theory and the measurement of sustainable development: an indicator of 'weak' sustainability," Ecol. Econ., vol. 8, no. 2, pp. 103108, 1993.

[4] I. Puspita, L. Ibrahim, and D. Hartono, "Pengaruh Perilaku Masyarakat yang Bermukim di Kawasan Bantaran Sungai Terhadap Penurunan Kualitas Air Sungai Karang Anyar Kota Tarakan (Influence of The Behavior of Citizens Residing in Riverbanks to The Decrease of Water Quality in The River of Karang)," J. Mns. dan Lingkung., vol. 23, no. 2, p. 249, 2016.

[5] BPS, Annual Report (Indonesian Statistics). Jakarta: Central Statistics Agency, 2018.

[6] BPS, Annual Report (East Java in Numbers). Surabaya: Central Statistics Agency, 
2018.

[7] BPS, Annual Report (Bengkulu in Numbers). Bengkulu: Central Statistics Agency.

[8] M. Ridwan, "Penguatan Ekonomi Masyarakat Berbasis Kelompok," J. Ekon. Pembang.

Kaji. Masal. Ekon. dan Pembang., vol. 13, no. 2, p. 207, 2012. 